Research Article

\title{
Effectiveness of Distraction Therapy on Pain Relief among Children Undergoing Vein-Puncture in a Selected Hospital, Bhubaneswar
}

\author{
Soumika Debnath', Niyati Das',, Purnima Sahoo ${ }^{3}$
}

${ }^{1}$ M.Sc. Nursing, Pediatric Nursing-(Kalinga Institute of Nursing Sciences, KIIT Deemed to be University, Bhubaneswar, Odisha. and Tutor, Apollo Gleneagles Nursing College, Kolkata.

${ }^{2}$ Professor Cum Vice Principal, RNRM, M.Sc. (N). in Child Health Nursing, H.O.D, Dept. of Pediatric Nursing- Kalinga Institute of Nursing Sciences, KIIT Deemed to be University, Bhubaneswar, Odisha.

${ }^{3}$ Asst. Professor, RNRM, M.Sc. (N) iN Child Health Nursing-Kalinga Institute of Nursing Sciences, KIIT Deemed to be University, Bhubaneswar, Odisha.

DOI: https://doi.org/10.24321/2349.7181.202008

I $\quad \begin{array}{lllll}\mathbf{N} & \mathbf{F} & \mathbf{O}\end{array}$

\section{Corresponding Author:}

Soumika Debnath, Pediatric Nursing-(Kalinga Institute of Nursing Sciences, KIIT Deemed to be University, Bhubaneswar, Odisha. and Tutor, Apollo Gleneagles Nursing College, Kolkata.

E-mail Id:

soumikadebnath@gmail.com

Orcid Id:

https://orcid.org/0000-0001-8684-4973

How to cite this article:

Debnath S, Das N, Sahoo P. Effectiveness of Distraction Therapy on Pain Relief among Children Undergoing Vein-Puncture in a Selected Hospital, Bhubaneswar. J Adv Res Med 2020; 7(2): 15-21.

Date of Submission: 2020-08-27

Date of Acceptance: 2020-11-28
$\begin{array}{llllllll}\mathbf{A} & \mathbf{B} & \mathbf{S} & \mathbf{T} & \mathbf{R} & \mathbf{A} & \mathbf{C} & \mathbf{T}\end{array}$

Aim: The present study is aimed to assess the effect of distraction therapy during venipuncture in reducing pain among 6-12 years children in the selected hospital at Bhubaneswar.

Methods: The study was a double blind; Randomized control trial design was used and the formal consent was obtained from Pradyumna Bal Memorial Hospital and the investigator selected 182 samples using consecutive sampling technique and then randomized into experimental and control groups. The intervention group and the control were having 91 samples each. Measurement of pain experienced by the school going children was assessed with the help of Wong-Baker Faces Pain Scale. Descriptive and inferential statistics were used to analyze the data.

Result: The mean pain score of children in experimental group was 2.571 and the standard deviation was 2.006. The $p$ value in comparing the pain level of children in control and experimental group was $<0.01$, which was statistically significant at $p<0.05$ (confidence interval 95\%) level indicating that there was significant difference in the post test level of pain between the experimental and control group.

Conclusion: Hence the distraction therapy was responsive in reducing the vein-puncture pain among school going children.

Keywords: Distraction Therapy, Pain, Vein-Puncture, Bhubaneswar

\section{Introduction}

Pain continues to be the most complex and challenging sensory emotions in the life of children. It is defined as a universal unpleasant, subjective, sensory and emotional human experience. Because of its strong sensation; it activates the sympathetic nervous system to alter the quality of life in children such as sleep, mobility, nutrition, thought, emotional wellbeing, and creativity. ${ }^{1}$ 
Needle puncturing is painful to all children but how they response to that depends on their developmental ages and their previous experiences. During venipuncture the nurse can provide various diversionary activities before, during and after procedure. ${ }^{2}$

Children should not be exposed to painful procedures. Despite the prevalence of pain stemming from medical procedures and the distress associated with this, research indicates that pain management continues to be suboptimal. Therefore, reducing the emotional and physical short-and long-term negative effects of painful procedures in children through adequate management is an important part of nursing practice. ${ }^{3}$

\section{Need of the Study}

Pediatric nursing is the specialized care of nursing practice concerning the care of children during wellness and illness. Pain is an unpleasant sensory and emotional experience associated with actual and potential damage. ${ }^{3}$

To the response of pain perception in children with acute and chronic disease is a major public health problem that has been increasing over the last 20 years. Elimination or relief of pain and suffering, whenever possible is as important responsibility of nurse caring for children, because unmanaged pain can result in a variety of negative long-term consequences. Vein-puncture is also a source of pain in hospitalized children. Vein-puncture was found to be the second most common cause of the worst pain experience during hospitalization. Before and during this procedure most children are fearful and suffer from pain and pain. ${ }^{4}$

\section{Problem Statement}

Effectiveness of distraction therapy on pain relief among children undergoing vein-puncture, in a selected hospital, Bhubaneswar.

\section{Hypothesis}

There is significant reduction of pain during vein puncture after using the distraction therapy.

\section{Objective of Study}

The overall study objective is:

- To evaluate the effectiveness of distraction therapy on pain relief among children during vein puncture.

- To find out the risk factors affecting the pain level.

\section{Literature Review}

A randomized control trial on distraction using the BUZZY for 4 to 12 years children during an IV insertion. They are divided into experimental and control group and each group was having 25 children. Then BUZZY was used in the experimental group. Wong-Baker FACES Pain Rating
Scale was used to rate the pain. BUZZY group was having less pain rating. ${ }^{5}$

A quasi-experimental study was done to compare between the effect of analgesic method among 7 years children. One group was held by family members and other group was held by family members as well as distraction therapy was used in second group. FLACC pain scale was used to assess the pain in both groups. Findings revealed that the mean pain score of group 1 was 3.86 and that of group 2 was 2.43 , while comparing both group pain scores 7.199 with p-value 0.000 was highly effective in group with distraction therapy. ${ }^{6}$

A control trial was conducted to assess the pain in 1 to $16 y e a r$ children during vein puncture procedure. A sweet tasting solution or substance was used as an interventional method. 330 samples were randomly divided in control and experimental group. In control group pacifiers and water substances were used. In Toddler group cry was very less so intervention was effective. ${ }^{7}$

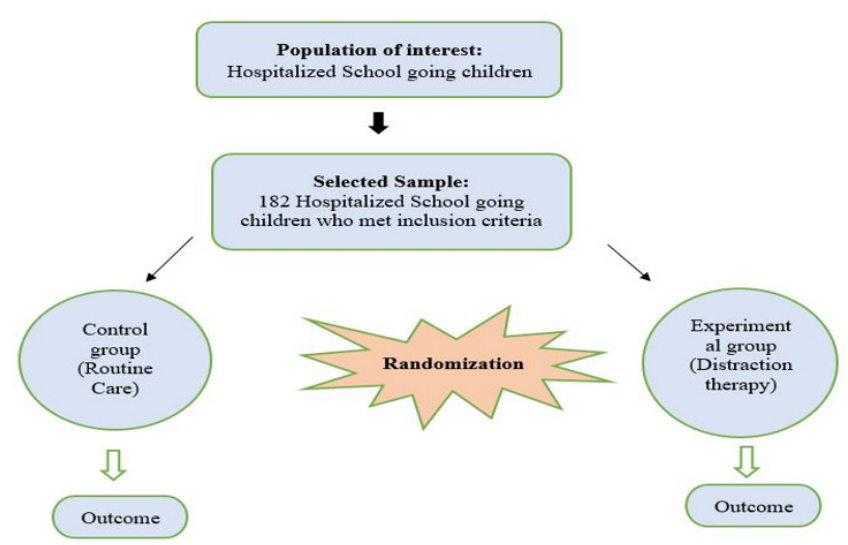

Figure I.Schematic diagram of research design Methodology

Randomized controlled trial design was used in this study. The study was conducted on children pediatric ward at Pradyumna Bal Memorial Hospital, KIMS. The samples selected for the present study were school going children of Pradyumna Bal Memorial Hospital, KIMS. In this study sample consists of 182 school going children who met the inclusion criteria.

The sample was selected for this study by adopting Consecutive Sampling (taking every patient who meets the selection criteria over the specified time period) and then randomized into experimental and control groups.

By taking into consideration the SD of WBFPS in distraction group and control group as $2.68 \& 4.12$ respectively with mean difference of 1.44 at $5 \%$ level of significance and $80 \%$ of minimum study power the sample size is 91 in each of the distraction and control group, the total sample size is 182 


\section{Inclusion Criteria}

- Children aged between 6-12 years.

- Children undergone vein puncture (IV cannulation, Blood collection).

- Children who are or whose parents are willing to participate.

\section{Exclusion Criteria}

- Children under gone any other procedure such as central line, arterial line etc.

- Syndromic babies, neurodevelopmental disorder.

- Visual and hearing impairment, verbal difficulty.

- Patient who used analgesics within 6 hours.

\section{Result}

\section{Description of Tool}

Socio-Demographic Data

Socio-Demographic data of the subjects consists of the following items: age, gender, birth order of the child, residence, type of family, religion, occupation of the father, educational qualification of the father, occupation of the mother, educational qualification of the mother, previous hospitalization within one year.

\section{Data Collection Procedure}

This was a prospective study that was conducted in the

\section{SCHEMATIC DIAGRAM OF RESEARCH METHODOLOGY:}

Effectiveness of distraction therapy on pain relief during vein puncture among children

Research Approach

Quantitative research approach

$\downarrow$

Research Design

Randomized controlled clinical trial

Target population

Children of pediatric general ward.

Accessible population

Schooler children of Pradyumna Bal Memorial Hospital, KIMS.

Sampling technique

Consecutive Sampling

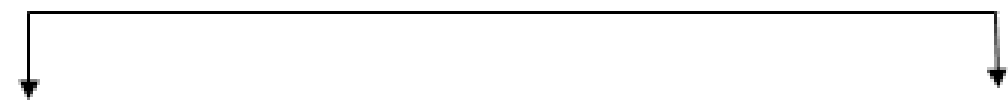

Intervention group

$\downarrow$ During Vein-puncture

Intervention (distraction therapy)
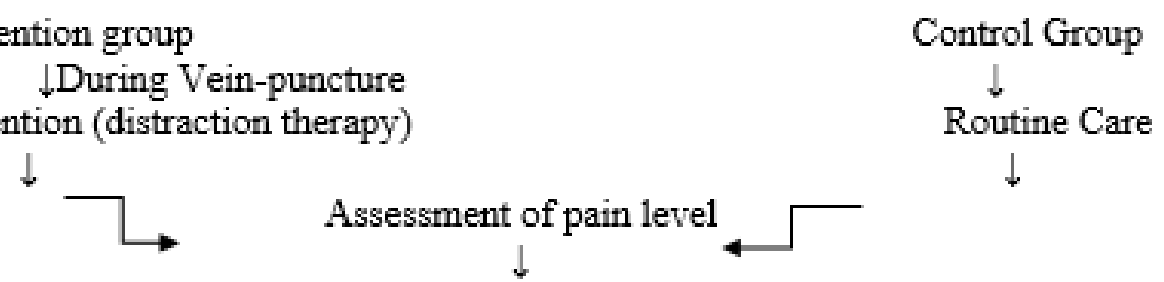

Analysis and interpretation

\section{Findings}

Figure 2.Schematic Diagram of Research Study 
phlebotomy room of KIMS hospital, in which the effect of distraction therapy (music + distraction card) was seen on pain relief among school going children. The children were randomized into two groups: experimental group (91) and control group (91) using a random table. First the socio demographic history of the child was collected. During the phlebotomy process one music (Hindi cartoon audio songs, ex-chhotabheem, Doremon) and then distraction card was shown to the child and questions were asked regarding the cards. The phlebotomy was performed using a $5 \mathrm{ml}$ syringe and 22 G, 24 G needle. Pain level of children in the experimental group were assessed by Wong Bekar Faces Pain Scale. In control group only, the routine hospital care was given during vein puncture.

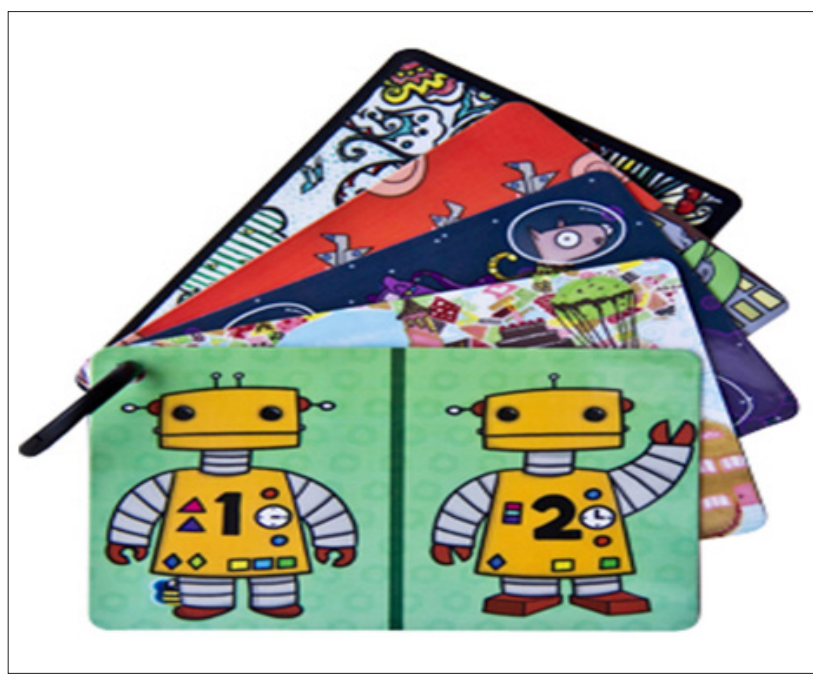

Figure 3.Distraction Card used in the study

Data Analysis

Statistical analysis was performed using STATA 1.5 software. Two sample ' $\mathrm{t}$ ' test and ANOVA were done to test the association of variables and to measure the effect of distraction therapy.

Pattern of Socio-Demographic Characteristics between Experimental and Control Group

Table I.Mean score of age in control and experimental group [N= I $82(\mathrm{nI}=91, \mathrm{n} 2=91)]$

\begin{tabular}{|c|c|c|}
\hline Group & Mean \pm Standard deviation & p-value \\
\hline $\begin{array}{c}\text { Age in control } \\
\text { group }\end{array}$ & $8.802 \pm 0.557$ & 0.995 \\
\hline $\begin{array}{c}\text { Age in } \\
\text { experimental } \\
\text { group }\end{array}$ & $9.16 \pm 0.556$ & \\
\hline$(p=0.05)$ &
\end{tabular}

Table 1, shows that mean score of age in control group was 8.802 and in experimental group was 9.16 which was not statistically significant.
Table 2.Frequency and percentage distribution of gender in control \& experimental group $[N=182$

$$
(\mathrm{n} I=91, \mathrm{n} 2=91)]
$$

\begin{tabular}{|c|c|c|c|c|c|}
\hline \multirow{2}{*}{$\begin{array}{l}\text { Charac- } \\
\text { teristics }\end{array}$} & \multicolumn{2}{|c|}{ Control group } & \multicolumn{2}{|c|}{$\begin{array}{c}\text { Experimental } \\
\text { group }\end{array}$} & \multirow{2}{*}{ p-value } \\
\hline & $\begin{array}{l}\text { Freq- } \\
\text { uency }\end{array}$ & $\%$ & $\begin{array}{l}\text { Freq- } \\
\text { uency }\end{array}$ & $\%$ & \\
\hline \multirow{3}{*}{$\begin{array}{c}\text { Gender } \\
\text { Female } \\
\text { Male }\end{array}$} & & & & & \multirow{3}{*}{0.882} \\
\hline & 43 & 48.86 & 45 & 51.14 & \\
\hline & 48 & 47.25 & 46 & 48.94 & \\
\hline
\end{tabular}

$(p=0.05)$

Table 2, shows that in female 43 (48.86\%) were in control group and 45 (51.14\%) were in experimental group. In male 48 (47.25\%) were in control group and 46 (48.94\%) were in experimental group. The $p$ value is not statistically significant.

Table 3.Frequency and percentage distribution of duration of hospital stay in control $\&$ experimental group $[N=182(n I=9 I, n 2=9 I)]$

\begin{tabular}{|c|c|c|c|c|c|}
\hline \multirow{2}{*}{$\begin{array}{c}\text { Charac- } \\
\text { teristics }\end{array}$} & \multicolumn{2}{|c|}{ Control group } & \multicolumn{2}{|c|}{$\begin{array}{c}\text { Experimental } \\
\text { group }\end{array}$} & \multirow{2}{*}{ p-value } \\
\cline { 2 - 5 } & $\begin{array}{c}\text { Freq- } \\
\text { uency }\end{array}$ & $\%$ & $\begin{array}{c}\text { Freq- } \\
\text { uency }\end{array}$ & $\%$ & \\
\hline $\begin{array}{c}\text { Duration } \\
\text { of } \\
\text { hospital }\end{array}$ & & & & & \\
stay & 43 & 52.44 & 39 & 47.56 & \\
$<3$ days & 33 & 48.53 & 35 & 51.47 & 0.868 \\
$3-7$ days & 15 & 46.88 & 17 & 53.13 & \\
$>7$ days & 15 & & & \\
\hline (p=0.05)
\end{tabular}

Table 4.Frequency and percentage distribution of previous hospitalization in control \& experimental group $[N=182(\mathrm{nl}=91, \mathrm{n} 2=91)]$

\begin{tabular}{|c|c|c|c|c|c|}
\hline \multirow{2}{*}{$\begin{array}{c}\text { Charac- } \\
\text { teristics }\end{array}$} & \multicolumn{2}{|c|}{$\begin{array}{c}\text { Control group } \\
\text { uency }\end{array}$} & $\%$ & $\begin{array}{c}\text { Experimental group } \\
\text { uency }\end{array}$ & $\begin{array}{c}\text { p- } \\
\text { value }\end{array}$ \\
\cline { 2 - 5 } $\begin{array}{c}\text { Previous } \\
\text { hospit- } \\
\text { alization }\end{array}$ & & & & & \\
None & 38 & 45.24 & 46 & 54.76 & \\
1 time & 35 & 54.69 & 29 & 45.31 & \\
2 times & 13 & 50.00 & 13 & 50.00 & 0.758 \\
3 times & 4 & 66.67 & 2 & 33.33 & \\
$>3$ times & 1 & 50.00 & 1 & 50.00 & \\
\hline$(p=0.05)$ & & \multicolumn{4}{|l}{} \\
\hline
\end{tabular}

Table 3, shows that in $<3$ days of hospital stay 43 (52.44\%) were in control group and 39 (47.56\%) were in experimental 
group. In 3 - 7 days of hospital stay 33 (48.53\%) were in control and 35 (51.47\%) were in experimental group. In $>7$ days of hospital stay 15 (46.88\%) were in control group and 17 (53.13\%) were in experimental group. The $p$ value is not statistically significant.

Table 4, shows that in no previous hospitalization 38 (45.24\%) were in control group and 46 (54.76\%) were in experimental group. In 1 time, 2 times, 3 times, >3 times 35 (54.69\%), 13 (50\%), 4 (66.67\%), 1 (50\%) were in control group respectively. In 1 time, 2 times, 3 times, >3 times 29 (45.31\%), 13 (50\%), 2 (33.34\%), 1 (50\%) were in experimental group respectively. The $p$ value is not statistically significant.

Table 5.Frequency and percentage distribution of mother's education level in control \& experimental group $[\mathbf{N}=182(\mathrm{nI}=91, \mathrm{n} 2=91)]$

\begin{tabular}{|c|c|c|c|c|c|}
\hline \multirow{2}{*}{$\begin{array}{l}\text { Charac- } \\
\text { teristics }\end{array}$} & \multicolumn{2}{|c|}{ Control group } & \multicolumn{2}{|c|}{$\begin{array}{c}\text { Experimental } \\
\text { group }\end{array}$} & \multirow{2}{*}{$\begin{array}{c}p- \\
\text { value }\end{array}$} \\
\hline & $\begin{array}{l}\text { Freq- } \\
\text { uency }\end{array}$ & $\%$ & $\begin{array}{l}\text { Freq- } \\
\text { uency }\end{array}$ & $\%$ & \\
\hline $\begin{array}{l}\text { Mother's } \\
\text { education }\end{array}$ & & & & & \\
\hline Primary & 27 & 50.94 & 26 & 49.06 & \\
\hline Secondary & 34 & 49.28 & 35 & 50.72 & \\
\hline $\begin{array}{c}\text { Higher } \\
\text { secondary }\end{array}$ & 24 & 50.00 & 24 & 50.00 & 1.000 \\
\hline $\begin{array}{l}\text { Graduate } \\
\& \text { above }\end{array}$ & 6 & 50.00 & 6 & 50.00 & \\
\hline
\end{tabular}

Table 5, shows that in primary education 27 (50.94\%) mothers were in control group and 26 (49.06\%) were in experimental group. In secondary education, higher secondary education, graduate and above 34 (49.28\%), 24 (50\%), 6 (50\%) were in control group respectively. In secondary education, higher secondary education, graduate and above 35 (50.72\%), 24 (50\%), 6 (50\%) were in experimental group respectively. The $p$ value is not statistically significant.

Table 6.Frequency and percentage distribution of place of residence in control \& experimental group $[N=182(\mathrm{nI}=91, \mathrm{n} 2=91)]$

\begin{tabular}{|c|c|c|c|c|c|}
\hline \multirow{2}{*}{$\begin{array}{c}\text { Charac- } \\
\text { teristics }\end{array}$} & \multicolumn{2}{|c|}{ Control group } & \multicolumn{2}{|c|}{$\begin{array}{c}\text { Experimental } \\
\text { group }\end{array}$} & \multirow{2}{*}{ p-value } \\
\cline { 2 - 5 } & $\begin{array}{c}\text { Freq- } \\
\text { uency }\end{array}$ & $\%$ & $\begin{array}{c}\text { Freq- } \\
\text { uency }\end{array}$ & $\%$ & \\
\hline $\begin{array}{c}\text { Residence } \\
\text { Rural }\end{array}$ & 44 & 48.35 & 47 & 51.65 & \\
Urban & 47 & 51.65 & 44 & 48.35 & 0.767 \\
\hline$(p=0.05)$ & & & & & \\
\hline
\end{tabular}

Table 7.Frequency and percentage distribution of health care professional in family in control $\&$ experimental group [N = I82 (nI = 9I, n2 = 9I)]

\begin{tabular}{|c|c|c|c|c|c|}
\hline \multirow{2}{*}{$\begin{array}{c}\text { Charac- } \\
\text { teristics }\end{array}$} & \multicolumn{2}{|c|}{ Control group } & \multicolumn{2}{|c|}{$\begin{array}{c}\text { Experimental } \\
\text { group }\end{array}$} & $\begin{array}{c}\mathrm{p}- \\
\text { value }\end{array}$ \\
\cline { 2 - 6 } & $\begin{array}{c}\text { Freq- } \\
\text { uency }\end{array}$ & $\%$ & $\begin{array}{c}\text { Freq- } \\
\text { uency }\end{array}$ & $\%$ & \\
\hline $\begin{array}{c}\text { Healthcare } \\
\text { professional } \\
\text { in parents } \\
\text { Yes } \\
\text { No }\end{array}$ & 1 & 33.33 & 2 & 66.67 & 1.000 \\
\hline$(p=0.05)$ & 50.28 & 89 & 49.72 & \\
\hline
\end{tabular}

Table 6, shows that in rural resident 44 (48.35\%) were in control group and 47 (51.65\%) were in experimental group. In urban resident 47 (51.65\%) were in control group and 44 (48.35\%) were in experimental group. The $p$ value is not statistically significant.

Table 7, shows that in control group and experimental group majority of the children 90 (50.28\%) and 89 (49.72\%) respectively were not having health care professionals in parents.

Difference of Pain Level during Vein Puncture between Control \& Experimental Group

Table 8.Difference of pain level during vein puncture between control \& experimental group (independent t test) $[N=182(\mathrm{nI}=91, \mathrm{n} 2=9 \mathrm{I})]$

\begin{tabular}{|c|c|c|c|}
\hline $\begin{array}{c}\text { SCORE } \\
\text { (During } \\
\text { vein } \\
\text { puncture) }\end{array}$ & $\begin{array}{c}\text { Control group } \\
\text { (Mean } \pm \text { SD) }\end{array}$ & $\begin{array}{c}\text { Experimental } \\
\text { group } \\
\text { (Mean } \pm \text { SD) }\end{array}$ & p-value \\
\hline Pain Score & $6.374 \pm 2.365$ & $2.571 \pm 2.006$ & 0.000 \\
\hline
\end{tabular}

$(p=0.05)$

Table 8, shows pain level in control group and experimental group are 6.374 and 2.571 respectively which is statistically significant. The $p$ value in comparing the pain level of children in control and experimental group was 0.000 , which was statistically significant at $p<0.05$ level indicating that there was significant difference in the post test level of pain between the experimental and control group

\section{Association of Pain Score with Demographic Variables}

The duration of hospital stay of the children in experimental group was associated with the level of pain. It was seen that longer the duration of hospital stays greater the adaptation to pain in vein-puncture procedure among children. The 
calculated $p$-value was 0.012 which is less than the level of significance $p<0.05$. This is statistically significant.

The number of previous hospitalizations was also associated with the level of pain among children in the experimental group. The calculated $p$ value was 0.017 which is less than the level of significance $p<0.05$. This is statistically significant which means children with previous hospitalization (>3 times) feeling more pain as compared to first admission.

The other variables were not associated with the pain level of children.

\section{Discussion}

The first objective was to assess the effectiveness of distraction therapy in reducing pain during vein-puncture by comparing the pain scores among both groups.

Control group which consists of 91 children, undergone vein-puncture by routine hospital procedure. During veinpuncture procedure the pain level of the children was assessed by Wong Bekar Facial Pain Scale. The score range of children in control group was 2-10. The mean pain score of children undergoing vein-puncture in control group was 6.374 and the standard deviation was 2.365 .

Experimental group which is consists of 91 children, received distraction therapy (music+ distraction card) during vein puncture. Then their pain level was assessed by using Wong Bekar Facial Pain Scale. The score range of children in control group was $0-8$. The mean pain score of children in experimental group was 2.571 and the standard deviation was 2.006 .

The $p$ value in comparing the pain level of children in control and experimental group was $<0.01$, which was statistically significant at $p<0.05$ level indicating that there was significant difference in the post test level of pain between the experimental and control group.

In a similar study the mean pain score of group 1 was 3.86 and that of group 2 was 2.43. The comparison of mean pain score of both groups was checked statistically by computing independent t-test and the value of $t$ comes out to be 7.199 with $p$-value 0.000 which was found to be highly significant. ${ }^{8}$

Another similar study revealed that the calculated unpaired ' $t$ ' value (3.81) is greater than tabulated value (2.04) during venipuncture and the calculated unpaired ' $\mathrm{t}$ ' value (5.06) is greater than tabulated value (2.04) after venipuncture. This indicates that there is statistically significant difference between the mean post assessment pain score value of experimental and the control groups $(p<0.05) .{ }^{9}$

Results of another study was mean pain score in experimental group was lower (4.6) than that of the control group (7.7) with the mean difference of 3.1 which was significant as evident from " $\mathrm{t}$ " value of (10) at 0.05 level of significance. ${ }^{10}$ In another similar study the mean pain score was significantly less with animated cartoon $(2.26 \pm 2.18)$ as compared to routine care $(4.76 \pm 2.08)$ at pre-venipuncture. Similarly, the mean pain score during venipuncture was significantly less with animated cartoon (6.24 \pm 2.09$)$ as compared to routine care (8.06 \pm 1.70$)$. During post-venipuncture also the mean pain score was significantly less with animated cartoon $(2.94 \pm 1.71)$ as compared to routine care $(5.94 \pm 1.61)$. The results revealed that there was significantly $(p<0.001)$ less pain related behavioral responses with the use of animated cartoons as a distraction strategy at pre-, during and postvenipuncture. ${ }^{11}$

\section{Conclusion}

The $p$ value in comparing the pain level of children in control and experimental group was 0.000 , which was statistically significant at $p<0.05$ level indicating that there was significant difference in the post test level of pain between the experimental and control group.

\section{Conflict of Interest: None \\ References}

1. Dutta P. Pediatric Nursing. Jaypee brother's Medical Publishers Pvt. Ltd., New Delhi. 2009.

2. Pain Scale, www.wikilovesmonuments.com, August.

3. Treesa E, Soud J, Roger S. Manual of pediatric emergency Nursing. 2nd ed. MOSBY, Philadelphia. 2008.

4. McLaren JE, Cohen LL. A comparison of distraction strategies for venipuncture distress in children. Journal of Pediatric Psychology 2005; 30(5): 387-396.

5. Harrison D, Yamada J, Adams-Webber T et al. sweet tasting solutions for reduction of needle-related procedural pain in children aged one to 16 years. The Cochrane Database of Systemic Reviews 2015; 5(5).

6. Mc Grath PJ, Unruh AM. Measurement and assessment of pediatric pain. 4th ed. Churchill Livingstone, New York, USA. 2004.

7. Lori H, Hamlin A, Diane W et al. Atraumatic care: EMLA cream and application of heat to facilitate peripheral venous cannulation in children. Issues in Comprehensive Pediatric Nursing 2009; 32(6): 23-26.

8. Gupta HV, Gupta VV, Kaur A, Singla R, Chitkara N, Bajaj $\mathrm{KV}$, Rawat HC. 'Comparison between the Analgesic Effect of two Techniques on the Level of Pain Perception During venipuncture in Children up to 7 Years of Age: A Quasi-Experimental Study. Journal of Clinical and Diagnostic Research: JCDR 2014; 8(8). https://www. ncbi.nlm.nih.gov/pubmed/25302240 (Accessed: 2nd April 2018).

9. Devi P, Shinde J, Patil B. Effectiveness of animated cartoon video as a distraction strategy on pain perception during and after venipuncture among 
preschoolers. International Journal of Psychiatric Nursing 2017; 3(1): 26-32. http://www.indianjournals. com/ijor.aspx (Accessed: 8th march 2017).

10. Shivcharan G, Jyotsna D, Shubhang B. Effectiveness of Cartoon Movies as Distracter on Pain among Children Undergoing Venipuncture. International Journal of Science and Research (IJSR) 2013; 6(14): 319-324. https://www.ijsr.net/archive/v5i6/NOV164843. pdf(Accessed: 28th February).

11. James J, Ghai S. The Effect of Distraction Techniques on the Pain of Venipuncture in Children: A Systematic Review. Journal of Pediatrics 2017; 5(1): 45-53. http:// jpediatricsreview.com/en/articles/9459.html (accessed 28th February 2018). 